\title{
DEVELOPING ENGINEERING MANAGERS: THE MASTER OF ENGINEERING MANAGEMENT PROGRAM AT MEMORIAL UNIVERSITY OF NEWFOUNDLAND
}

\author{
Amy Hsiao \\ Memorial University of Newfoundland \\ amy.hsiao@mun.ca
}

\begin{abstract}
The Master of Engineering Management (MEM) program in the Faculty of Engineering and Applied Science (FEAS) at Memorial University of Newfoundland (MUN) is one of the first designated MEM graduate programs in Canada. With a mandate to attract both local and international students from all engineering disciplines, and to provide balanced graduate training in Management and Engineering, the program has experienced increasing growth since it welcomed its first cohort in 2009. For the purpose of knowledge sharing and discourse, this paper will present details of the program and student characteristics, and discuss outcome assessment and future program planning.
\end{abstract}

Keywords: management, leadership skills, teamwork

\section{INTRODUCTION}

Engineering Management is an area of research and specialty that integrates the application of management skills and practice to engineering-based industries. Engineering management focuses on the technological problem-solving ability learned from an Engineering discipline and the organizational, administrative, and planning abilities of management in order to oversee complex enterprises from conception to completion. Engineering managers manage engineers who are normally driven by technical, non-entrepreneurial thinking, thus engineering managers require the necessary professional skills to coach, mentor and motivate other, fellow engineers. Traditionally, engineering professionals joining technology-based companies become engineering managers by default after a period of time in their career paths. They are required to learn how to manage once they are on the job, and the result is that they feel unprepared and lacking in training; overall, it is an ineffective way to develop managerial abilities.

It is for this reason that the MEM program at MUN was developed, i.e. it was a response to local industry expressing a need for this type of management and advanced technical training for its engineering professionals.

While the program at MUN is one of a handful of similar graduate programs in Canada, the specialty has been gaining reputation and validity with employers throughout North America. A Master in Engineering Management (MEM) degree is increasingly recognized as being equivalent to a Master of Business Administration (MBA) degree, geared for engineers in that fundamental management courses and graduate-level engineering courses are characteristic of a MEM program. A survey of the seven American universities that formed the Master of Engineering Management Programs Consortium in 2007, namely Stanford University, Dartmouth College, Cornell University, Northwestern University, Massachusetts Institute of Technology, University of Southern California, and Duke University, all show that even though each program has its unique focus and a defined theme, the programs all incorporate a interdisciplinary approach, taking from a balance of courses in Management and Engineering [1]. Standard core courses in Management include Marketing, Finance, Accounting, Strategy in High-Tech Industries, Entrepreneurship, Leadership and Organizational Behavior.

\section{PROGRAM DETAILS}

\subsection{Course of Study}

Memorial's MEM program is a course-based graduate program that can be completed on a full or parttime basis and draws on the expertise of both the FEAS and the Faculty of Business Administration (FBA). The completion of twelve courses results in a Master of Engineering Management, or MEM, degree. The program consists of five courses offered by the FEAS, five courses offered by the FBA, and a two-course project. These courses are shown in Table 1 . The program can be completed in four (4) semesters on a full-time basis, and 
students have up to nine (9) semesters to complete the program on a part-time basis.

The project course is a 6 -credit requirement that is normally completed in the last two semesters of a student's program. While there is flexibility to the topic chosen, there must be an evident technical component and a management component to the project. Project topics are usually student-driven, in that students pursue ideas based on their engineering background or interests, and in conjunction with a faculty advisor, the scope of work is defined.

Internships of up to 12 months are also available on a competitive basis for full-time MEM students who have completed all courses in the program.

Table 1: MEM Course Requirements

\begin{tabular}{|l|l|}
\hline FEAS Courses & FBA Courses \\
\hline $\begin{array}{l}\text { Engineering Management } \\
\text { Topics }\end{array}$ & Organizational Behaviour \\
\hline $\begin{array}{l}\text { Advanced Modeling and } \\
\text { Quality Management }\end{array}$ & Accounting \\
\hline 3 Engineering Electives & Marketing \\
\hline $\begin{array}{l}\text { Engineering Management } \\
\text { Project }\end{array}$ & $\begin{array}{l}\text { 2 Business Electives } \\
\text { (previously 1 elective and } \\
\text { Managerial Finance) }\end{array}$ \\
\hline
\end{tabular}

\subsection{Admission Requirements}

To be eligible for the program, applicants must have a Bachelor of Engineering or Bachelor of Science degree in an engineering discipline from a university of recognized standing, with a cumulative B-average (2.6/4.0). The application package includes two references, an academic transcript, a statement of interest, and a current resume. Relevant work experience is taken into consideration and is stated as being a preference for all interested applicants.

For international students, the program begins with an intensive eight-week session of English language instruction and an introduction to Canadian culture. Notwithstanding, admission requirements for international students include a TOEFL score of at least 80 for the Internet-based exam, and a minimum overall score of 6.5 on the IELTS test ${ }^{1}$. When possible, there is also a face-to-face interview with a university representative.

\subsection{Program Promotion and Outreach}

In the first nine months leading up to the first course offerings of the program in the Fall of 2009, intensive effort was exerted to promote and recruit for the program locally and internationally. Posters and brochures were made in English for distribution and sent to Canadian universities with engineering undergraduate programs. Posters were also made in Chinese for distribution on recruitment trips to China. An article announcing the new course-based programs in the FEAS was featured under a "Dean's column" in the Professional Society of Engineers and Geoscientists of Newfoundland and Labrador (PEGNL). Feature articles were published in the university newspaper, The Gazette, as well as the provincial newspaper, The Telegram, during Engineers Week. A print advertisement was placed in the January/February issue of Atlantic Business, a bi-monthly consumer publication founded in 1989 that covers all areas of business within the four Atlantic Provinces. It is the longest publishing regional business magazine in Atlantic Canada as well as the most award-winning and largest circulation business magazine in the region, publishing a minimum of 35,000 copies per issue. Atlantic Business follows a controlled circulation model of distribution that reaches business readers via The Globe \& Mail and places hard copies of issues in select locations such as airport executive lounges, major hotels and Marine Atlantic ferries.

In May 2013, another promotional effort was launched focusing on reaching the local industry, via a letter from the Dean of Engineering and an updated brochure sent electronically, by permission, through the PEGNL members' distribution list.

\subsection{Tuition and Fees}

The tuition and fees for the program are shown in Table 2. For students whose undergraduate study was not instructed in English, or whose first language is not English, the program begins in the summer before Fall admission with a course, Foundation English for Graduate Students, that serves as an orientation to the university, Newfoundland, and Canada as well.

Table 2: MEM Program

\begin{tabular}{|l|l|}
\hline $\begin{array}{l}\text { Fees Tuition } \\
\text { (International) }\end{array}$ & $\$ 22,000$ CAD \\
\hline Books & $\$ 1,000$ CAD(estimate) \\
\hline Living Expenses & $\$ 8,000$ CAD (estimate) \\
\hline Health Insurance & $\$ 1,000$ CAD (estimate) \\
\hline \hline $\begin{array}{l}\text { TUITION TOTAL } \\
\text { (International) }\end{array}$ & $\mathbf{\$ 3 2 , 0 0 0 ~ C A D ~}$ \\
\hline \hline Tuition (Canadian) & $\$ 16,000$ CAD \\
\hline Books & $\$ 1,000$ CAD (estimate) \\
\hline \hline $\begin{array}{l}\text { TUITION TOTAL } \\
\text { (Canadian) }\end{array}$ & $\mathbf{\$ 1 7 , 0 0 0 ~ C A D ~}$ \\
\hline
\end{tabular}

\footnotetext{
${ }^{1}$ English proficiency has since been increased, see section 5.1.
} 


\section{PROFILE OF STUDENTS}

Four cohorts of the program have been admitted to date, making a total of 45 students, averaging 11 students per entering class. Eight-two percent $(82 \%)$ of the students are full-time, and eighteen percent (18\%) are part-time students, holding full-time positions at local industries. Twenty-two percent (22\%) of MEM students are female. Approximately fifty percent $(50 \%)$ of the students have relevant work experience, having held fulltime technical positions, and of those students, the average is 3.5 years of work experience before pursuing the MEM degree. Among the 45 students, a variety of engineering backgrounds are represented: Electrical Engineering and Electronics Design, Computer Engineering, Ocean and Naval Architectural Engineering, Mechanical Engineering, Manufacturing and Industrial Engineering, Civil Engineering, Environmental Engineering, Biomedical Engineering, and Engineering Management.

Figure 1 shows the representation of nationalities of students in the MEM program. It can be seen that parttime students are mainly Canadian or local students, and the full-time students are mainly international students. On average, the international MEM students admitted scored $12 \%$ higher than the minimum TOEFL score requirement, and their average GPA in undergraduate studies was 2.8/4.0. The average GPA of noninternational students was slightly higher, at 3.2/4.0.

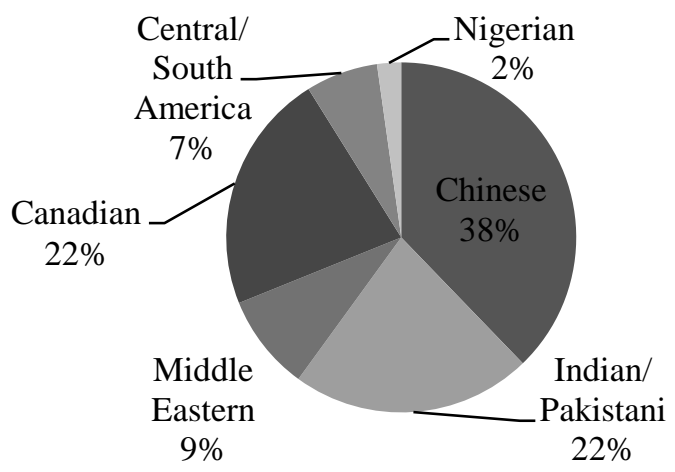

Fig. 1: Distribution of Nationalities Represented by MEM Students

\section{STUDENT OUTCOMES}

\subsection{Retention}

MEM students are required to maintain a grade of 65 or better in all courses, and two final marks below a 65 results in immediate withdrawal from the program. Student retention is currently ninety-one percent $(91 \%)$, with two withdrawals due to non-academic reasons, and two withdrawals due to failure.

\subsection{Performance in Management Courses}

Seventeen students (17) have graduated from the program since 2009. Of the seventeen, five (5) completed their undergraduate studies in English or considers English as their first language. Table 3 summarizes the average final grade in the required Management courses of Organizational Behaviour, Marketing, and Accounting.

Table 3: Final Marks in Management Courses

\begin{tabular}{|l|l|l|l|}
\hline Final Mark & $\begin{array}{l}\text { Org } \\
\text { Behaviour }\end{array}$ & Marketing & Accounting \\
\hline $\begin{array}{l}\text { All MEM } \\
\text { Students }\end{array}$ & 70 & 72 & 74 \\
\hline English & 76 & 76 & 78 \\
\hline
\end{tabular}

Figures 2, 3, 4 show the distribution of grades in relation to MEM students. It can be seen that native English speakers have average final marks that are higher than students who regard English as their second language. In addition, the number of MEM students receiving a final mark of 65 , implying that they are barely passing the core Management courses, is a concern.

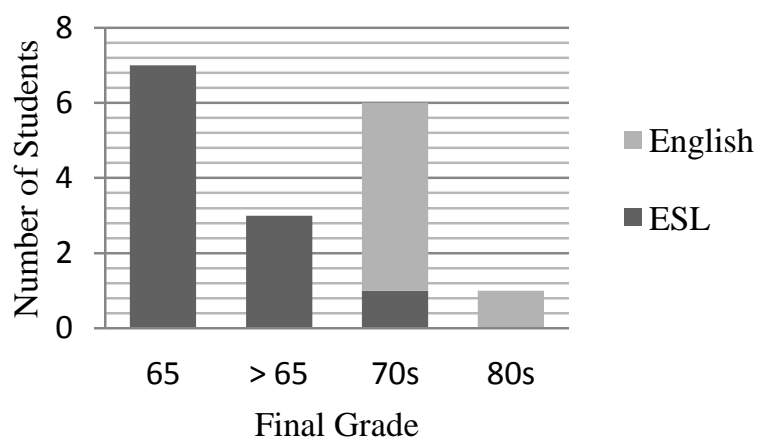

Fig. 2: Distribution of Grades for MEM Students in Organizational Behaviour

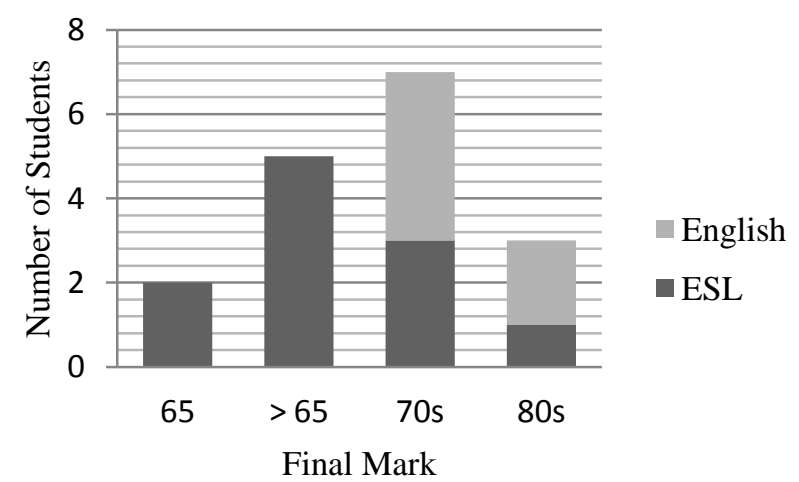

Fig. 3: Distribution of Grades for MEM Students in Marketing 


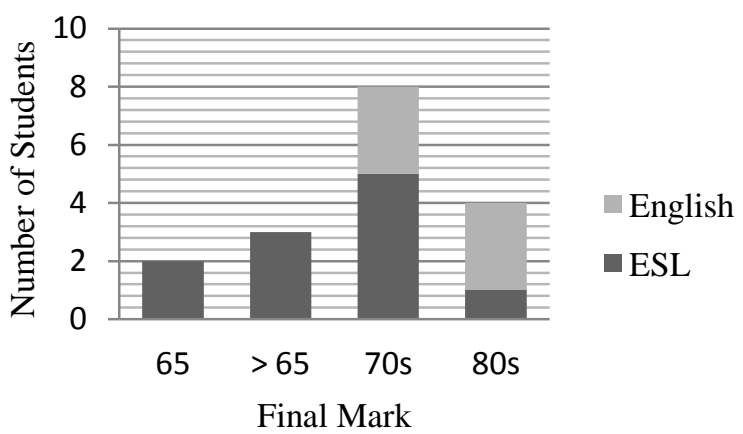

Fig. 4: Distribution of Grades for MEM Students in Accounting

\subsection{Performance in Engineering Courses}

Table 4 shows the average grades of MEM students in Engineering courses, including the core courses of Engineering Management Topics, Advanced Modeling and Quality Management, and the two-credit MEM Project course. It can be inferred from the data that English proficiency does not appear to have as much of an effect in Engineering courses as it does for Management courses.

Table 4: Final Marks in Engineering Courses

\begin{tabular}{|l|l|l|l|l|}
\hline $\begin{array}{l}\text { Final } \\
\text { Mark }\end{array}$ & $\begin{array}{l}\text { EM } \\
\text { Topics }\end{array}$ & $\begin{array}{l}\text { Modeling } \\
\text { \& QM }\end{array}$ & $\begin{array}{l}\text { MEM } \\
\text { Project }\end{array}$ & $\begin{array}{l}\text { 3 } \\
\text { Elects. }\end{array}$ \\
\hline $\begin{array}{l}\text { All } \\
\text { MEM } \\
\text { Students }\end{array}$ & 82 & 76 & 76 & 80 \\
\hline English & 83 & 76 & 74 & 80 \\
\hline
\end{tabular}

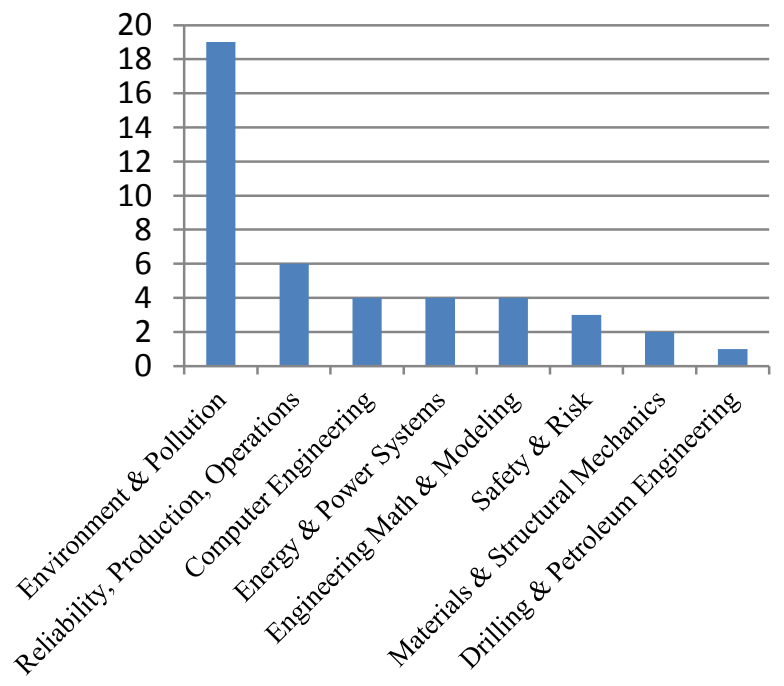

Fig. 5: Categories of Engineering Electives Selected by MEM Students
Figure 5 shows the engineering topics that are chosen by MEM students to fulfill their elective requirements. The most popular courses are in the Environment and Pollution category, and this is selected by all MEM students, not only students with Civil or Environmental Engineering backgrounds.

\subsection{Project Focus}

The MEM project is normally undertaken towards the end of a student's program as a team project or an individual project. Flexibility is allowed in the design of the project, but the project must have a technical or engineering component and a management component. Projects are usually student-initiated but the students must work in conjunction with a faculty member, who also serves as the student's supervisor. Some possibilities for projects include:

$$
\begin{array}{ll}
\circ & \text { Feasibility studies } \\
\circ & \text { Survey research projects } \\
\bigcirc & \text { Applied research projects } \\
\circ & \text { Case studies }
\end{array}
$$

All projects require a progress presentation and a final written report, with research methodologies that may include:
○ Theory development
$\circ \quad$ Design of independent study
- Proposition/model development
- Primary data collection \& analysis

For part-time students who are employed full-time, research projects may be related to the students' work environment, providing that the project has academic rigour and there is evidence of applied learning. The scope of the project must be beyond the work performed in other course projects and beyond any report effort required by a student's employer.

The variety of MEM projects have been the most indicative of the students' ability to apply what they have learned in MEM courses and pursue specific research interests not available through course offerings. A sample of topics of MEM projects to date include:

- A Statistical Analysis of Tanker Collision Causes and Factors

- A Soil Remediation Framework for China's Pearl River Delta using Labrador Examples

- Business Feasibility Plan for a Recycled Tires-toConstruction-Materials Company

- Computer Engineering's Role in the Financial Sector in China

- Business Feasibility Plan for a Recycled-LumberWaste-to-Biofuels Company

- Evaluation of Six-Sigma for the Service Industry 
- Lean Management Improvements to a Shanghai Shipping Port using St. John's Port as an Example

- Evaluation of Construction Waste Recycling Opportunity in Southern China

- Marketing Plan for a Technology Product

- The Evolving Role of Women in Engineering: Past, Present, Future

- A Framework for Knowledge Management and Project Management in Small-Medium Enterprises

- Soil Remediation Analysis for a Site in Happy ValleyGoose Bay Statistical Evaluation of Battery Life in Wildlife Monitoring Devices

- Design and Business Model for a Decentralized StandAlone Solar PV Off-Grid Electrical Power System for Rural Community in Nigeria

- Business Feasibility Plan for a Recycled-Plastics-Paper Company in Belize using St. John's Recycling as an Example

- $\quad$ The Role of Engineering Managers in the Offshore Oil Industry in Newfoundland

\subsection{Employability}

Figure 6 shows the percentage of graduates who have gained employment as a result of the MEM degree, i.e. they are now employed in an engineering position that requires management or leadership skills.

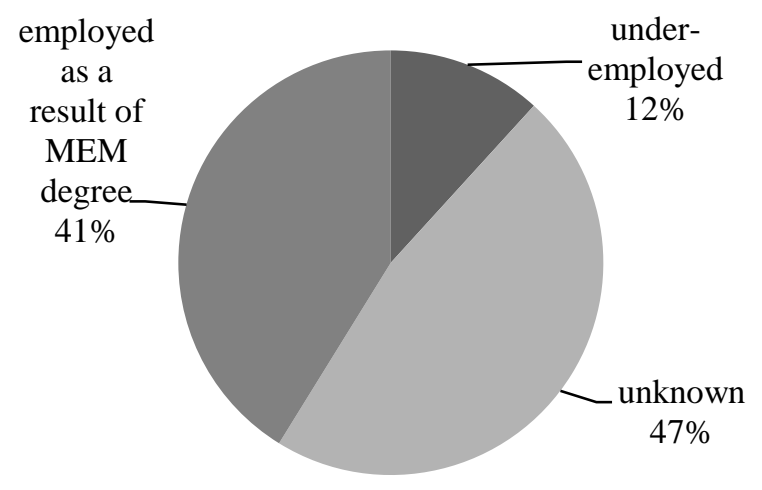

Fig. 6: Percentage of Graduates Employed in MEM Roles

\section{DISCUSSION}

\subsection{Program Evaluation}

The MEM Board of Studies undertook a 3-year selfassessment of the program of study in the Fall of 2011. The results of this informal self-assessment were changes to the Calendar, mainly on program logistics to improve the quality of intake, i.e. an increase in the admission requirements for English proficiency was made, to TOEFL online scores of 92-93 and IELTS score of 7.0 or better. The incoming class of Fall 2013 were selected based on these changes in requirements.

In addition, Managerial Finance was removed as a core Business requirement and added to the expanded list of Business electives that could be selected. As such, the number of Business electives was increased to two.

In outcome assessment endeavors, the first point to address is a re-evaluation of the objectives. Given that the objectives of the MEM program were to:

- Address the local call to create a graduate-level, course-based program that provided local industries to train their engineering professionals in management,

- Participate in the global impetus for engineering professionals trained in management,

a survey of recent graduates and current students would most likely best address the success of these two objectives. Preliminary feedback from part-time MEM students have been that the core courses have all been relevant and well-taught, but that a course in Project Management would be useful, and more practical applications, as opposed to only a theoretical mathematics focus, can be emphasized in courses such as "Advanced Modeling and Quality Management". MEM students would also like to see more Engineering electives in timeslots that fit their full-time employment schedules, i.e. during the early morning, lunch hour or after work, once a week or on the weekends. Overall, students are not positive about online courses and online instruction.

\subsection{Future Assessment}

The MEM Board of Studies would like to undertake a more formal five-year assessment of the program in Fall of 2014. The student outcomes presented here, i.e. retention, performance in Management courses, performance in Engineering courses, the significance of English proficiency for non-native speakers on their success in MEM courses, quality of projects, and employability, are all suitable measures to consider. However, it would be useful to implement other assessment factors and understand assessment tools, such that a better correlation between admitted students, and their resulting failure or success in the program, is made. Questions such as,

- "How do we change the number of MEM students 'barely passing' their courses to ours being the best quality students amongst M.B.A., M.Eng., and Ph.D. students, whom MEM students are in class with?"

- "What else should we be looking for in the admissions process?"

- "Should there be more emphasis on relevant work experience, and if so, what is the correlation?"

- "How does English proficiency relate to the "soft skills' required of engineering managers?" 
Research has shown that professional, or "soft skills," are equally important in technology-based industries as technical skills [2], as well they are a large component of an engineering manager's day-to-day role [3]; therefore, an evaluation of how well MEM students are developing these "soft skills" through the program of study offered is critical. Such "intangible" outcomes that measure professionalism, conduct, and integrity would be important. In addition, an assessment of how effective recruitment efforts have been, to local, national, and international students, would be beneficial.

\section{CONCLUSION}

The MEM program at Memorial University of Newfoundland is one of a few specifically designated MEM graduate programs in Canada. In its fourth year of offering, enrollment has increased fifteen-fold, with a good blend of local and international, part-time and fulltime, and women and men students from various Engineering backgrounds. This paper presented the initial findings from an evaluation of basic, primary data of current MEM students and recent graduates to consider the success and validity of the purpose and relevance of MUN's MEM program for those in engineering professions. This paper seeks to consider other assessment factors and tools, through discourse with CEEA attendees, and ways to improve the MEM program at Memorial University going forward.

\section{Acknowledgements}

The author wishes to acknowledge Dr. Tom Cooper and Prof. Peggy Coady from the Faculty of Business Administration, and Dr. Lesley James and Prof. Andy Fisher, from the Faculty of Engineering and Applied Science, who are members of the MEM Board of Studies.

\section{References}

[1] "Master of Engineering Management Programs Consortium," www.mempc.org, last retrieved May 1, 2013.

[2] A. Hsiao, The Master of Engineering Management Program at Memorial University of Newfoundland. American Society of Engineering Educators 2011 Conference and Exposition, AC2011-918.

[3] J.V. Farr and D.M. Brazil, Leadership Skills Development for Engineers. Engineering Management Journal, Vol. 21 No. 1, March 2009, 3-8.

[4] A.P. Ammeter and J.M. Dukerich, J.M. Leadership, Team Building, and Team Member Characteristics in High Performance Project Teams. Engineering Management Journal, Vol. 14 No. 4, December 2002, pgs. 3-10. 